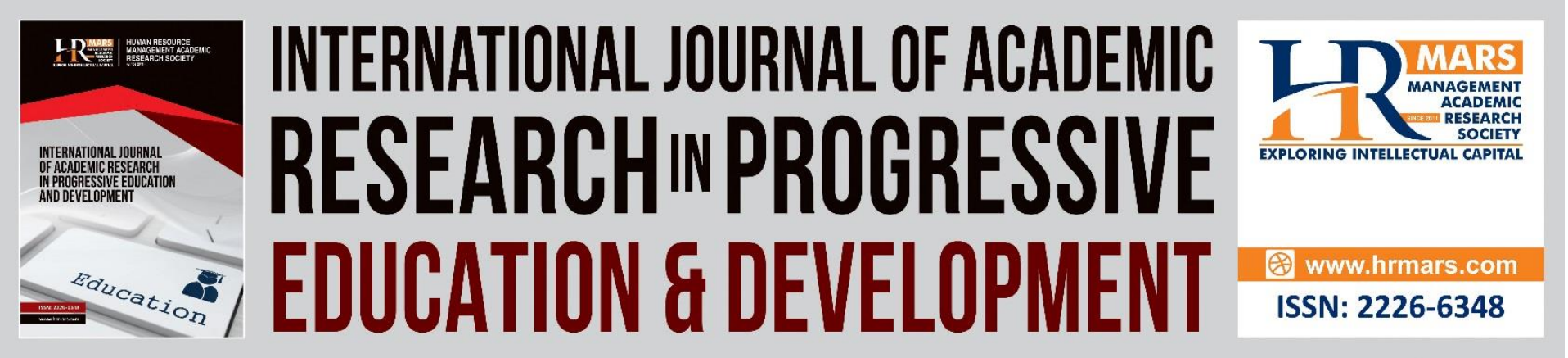

\title{
Society Empowerment Through Sex Education Based on Islamic Framework: A Study on Transgender
}

Wan Mohd Khairul Firdaus Wan Khairuldin, Hasanulddin Mohd, Wan Nur Izzati Wan Nor Anas, Mohd Sufi Ibrahim, Sharul Fitry Abdul Majid, Zureen Yusoff

To Link this Article: http://dx.doi.org/10.6007/IJARPED/v11-i1/12250

DOI:10.6007/IJARPED/v11-i1/12250

Received: 11 November 2021, Revised: 12 December 2021, Accepted: 06 January 2022

Published Online: 26 January 2022

In-Text Citation: (Khairuldin et al., 2022)

To Cite this Article: Khairuldin, W. M. K. F. W., Mohd, H., Anas, W. N. I. W. N., Ibrahim, M. S., Majid, S. F. A., \& Yusoff, Z. (2022). Society Empowerment Through Sex Education Based on Islamic Framework: A Study on Transgender. International Journal of Academic Research in Progressive Education and Development, 11(1), 645-650.

Copyright: (C) 2022 The Author(s)

Published by Human Resource Management Academic Research Society (www.hrmars.com)

This article is published under the Creative Commons Attribution (CC BY 4.0) license. Anyone may reproduce, distribute, translate and create derivative works of this article (for both commercial and non-commercial purposes), subject to full attribution to the original publication and authors. The full terms of this license may be seen

at: http://creativecommons.org/licences/by/4.0/legalcode

Vol. 11(1) 2022, Pg. $645-650$

http://hrmars.com/index.php/pages/detail/IJARPED

JOURNAL HOMEPAGE

Full Terms \& Conditions of access and use can be found at http://hrmars.com/index.php/pages/detail/publication-ethics 


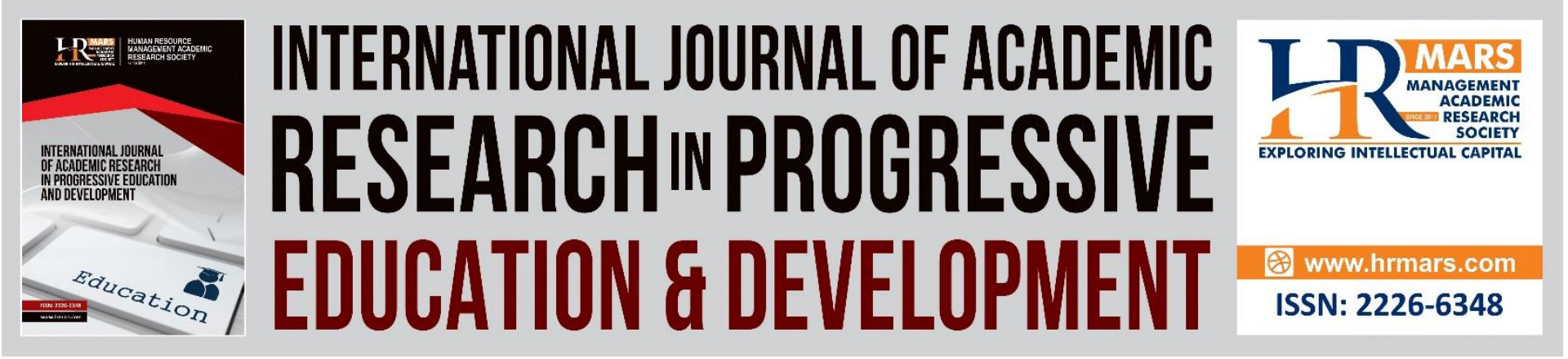

\title{
Society Empowerment Through Sex Education Based on Islamic Framework: A Study on Transgender
}

\author{
Wan Mohd Khairul Firdaus Wan Khairuldin ${ }^{1}$, Hasanulddin \\ Mohd ${ }^{1}$, Wan Nur Izzati Wan Nor Anas², Mohd Sufi Ibrahim', \\ Sharul Fitry Abdul Majid ${ }^{1}$, Zureen Yusoff ${ }^{3}$ \\ ${ }^{1}$ Faculty of Islamic Contemporary Studies, Universiti Sultan Zainal Abidin, ${ }^{2}$ Academy of \\ Islamic Studies, University of Malaya, ${ }^{3}$ Pertubuhan Kembara Mahabbah, Selangor \\ Email:wanfirdaus@unisza.edu.my
}

\begin{abstract}
Social problems related to sex, especially transgender problems, often cause concern among the Muslim community in Malaysia. In fact, transgender people in Malaysia move through various mediums so that the enforcers face problems in their efforts to curb their development. Some communities also see transgender as a form of normalization that does not bring negative impact. However, Islam takes the issue of transgender very seriously and always puts strict guidelines so that transgender problems do not occur at all. Therefore, education on sexual issues to the Muslim community needs to be streamlined in line with Islamic demands through the text of the Quran, hadith and classical and contemporary Islamic scholars. This study aims to identify a model of Islamic sexual education that focuses on efforts to combat the development of transgender problems. The data collection of this study used documentation method which was then analyzed using content analysis method. The findings of the study found that Islam is very strict in forbidding the involvement of its followers in social problems, especially transgender people. Sexual education based on the Islamic framework needs to be disclosed to the community in order for this maqasid syariah (objectives of Shariah) to be achieved.
\end{abstract}

Keywords: Empowerment, Sex Education, Islamic Framework, Transgender.

\section{Introduction}

Humans are naturally grouped into different genders whether male or female based on the genitals at birth. According to Bishop and Osthelder (2001), an individual sometimes thinks he was born of the wrong gender so that he has a desire to live thinking that he was born of the wrong gender and has a desire to live a different gender than the original. This is because they are uncomfortable to their original gender. If an individual's behavior in society does not follow the norm or deviate, it is considered abnormal behavior. According to Azizi Yahya and Jamaludin Ramli (2007), the abnormality occurs in individuals who experience symptoms of 
disorderly behavior due to organic or psychological factors. These individuals usually behave strangely and oddly out of the norm of society and are sometimes categorized as disorderly or disorderly.

According to Calimach (2000), the history of transgender has started since time immemorial starting from the Indian-American society giving permission to men who live like women to have a husband. The issue of transsexuality is also a negative phenomenon that has hit Malaysia lately. According to Teh (2001), it is estimated that there are around 100,000 transgender men in Malaysia. This number is constantly increasing rapidly due to the absence of effective solutions.

This issue is even more problematic when Malaysia as a country that recognizes Islam as a federal religion does not have special provisions in addressing transgender issues. Although in 1983, the Conference of Rulers (Majlis Raja-Raja) issued a fatwa on the prohibition of gender reassignment for Muslims, but this fatwa or law has not been gazetted by fatwa institutions in Malaysia untill now (Malib \& Mustafa, 2014). Gender reassignment in Malaysia is considered a personal matter that has an element of religious sentiment. Each offender will be punished according to the provisions enshrined in the law based on the religion of the offender.

To solve this problem, sexual education needs to be given attention by those in charge. Islamic scholars and scholars have discussed matters related to sex education. Sex education should be taught to community especially to the children because it meets the demands of daily human life based on Islamic law, in addition to avoiding reverse sexual behavior and prohibited by Islam (Ulwan, 2009). Therefore, this article will place some Islamic emphasis on the concept of sex education to address transgender issues among the Muslim community.

\section{Methodology}

This study adopts a qualitative method with basic research design. Secondary data is collected from the secondary sources such as literature, reports and documents that are related to Islam education, also on sexual education. The data then analyzed using content analysis method.

\section{Findings}

Transsexual is the condition of a person having an instinct by identifying his or her gender with the opposite sex of his or her original gender. Therefore, usually they will do something to change their physical condition so that their physical resembles the opposite sex to their original gender. These transgender people actually suffer from gender confusion because they feel themselves trapped in other people's bodies. This is because they want their gender to be the opposite sex to their original gender (Ghazali et al. 2011).

Islam is a comprehensive religion in all matters. Islam also provides rules on human beings in a matter even in the smallest of matters. This can be seen when Allah SWT sets the rules that every man and woman have to follow. These rules include matters of worship, munakahat, crime and muamalat. Although the rules set for men and women have differences in certain matters. However, this does not mean that Islam is a religion that is biased towards one sex because Islam lays down the rules based on the suitability of gender nature. 
Allah SWT created human beings with two different genders namely male and female. Allah SWT says in surah al-Nisa' verse 1 :

"O humanity! Be mindful of your Lord Who created you from a single soul, and from it $\mathrm{He}$ created its mate,and through both He spread countless men and women. And be mindful of Allah-in Whose Name you appeal to one another-and 'honour' family ties. Surely Allah is ever Watchful over you."

(al-Nisa' 4:1)

This verse explains the creation of man into two forms of gender only, namely male and female. However, the effort to change the original gender creation to a different gender as done by transgender people is a matter that is contrary to Islamic principles.

Emphasis on the need for sex education began to emerge as statistics related to moral decay such as free association, transgender issues, extramarital intercourse and AIDS increased from time to time. Discussions regarding the teaching and learning of sex education are not something that Islam opposes. In the Qur'an and Hadith, there are a lot of discussion regarding the sex and gender issue, especially related to health such as prayer, fasting, bathing, marriage, divorce, human relationships and so on. Sex education in Islam also demanded in educating children from the beginning (Sarwar 1996). To ensure that the Muslim community receives the sex education recommended in Islam, the elements in sex education must have Islamic values guided by the teachings of the Quran and Hadith. Things that are halal and haram in Islam should be emphasized in shaping human beings who have pure and praiseworthy morals (Al-Afendi, 1980).

There are several principles of sex education that can be utilized in an effort to prevent transgender problems from continuing to occur.

First, gender education to the community. Education is not just a learning process but is a source of all knowledge, therefore it is an effective instrument of value transfer, including values related to gender issues (Muawanah, 2009:65). Gender as part of cultural development can be transformed through the education process in schools. The values and norms in society will be transformed both explicitly and hidden through written texts in textbooks and in treatments that reflect the prevailing values of gender equality.

Allah SWT says in Surah al-Fatir, verse 11: "Allah created you from dust, then from a little fluid, then He made you pairs (the male and female)." (al-Fatir, 11). This verse explains the position of the Islamic gender which is only divided into two parties. In making the society understand the concept of gender, a clear education should be given to the society about the concept of gender and the differences between each of these genders. This can make the community put a guide for them not to belong to the transgender group. In fact, in another angle, education about gender can also be focused on the Islamic view of each of these genders.

Second, cultivale shyness from children age. Shyness should be instilled in children from an early age, especially in relation to the genitals. Shyness is to keep from committing sins by ensuring that oneself is always kept away from unhealthy activities as well as reading 
materials and entertainment that can damage one's faith. The nature of shy will also make oneself istiqamah in doing good. Even in matters forbidden by Islam, this concept of shame needs to be emphasized so that every offender feels they need to change their behavior.

The Prophet Rasulullah PBUH said: "Shy and Faith go hand in hand. If one of them is lost, then the other is also lost" (Narrated by al-Hakim). in transgender issues, the concept of shy especially in cases involving sexual treatment needs to be given priority. This is because the issue of normalization among societies about transgender has become a common thing (Teh, 2008). This causes most of them not to feel ashamed and awkward to be in public with different genders and attire.

Third, instilling the spirit of masculinity in boys and the spirit of femininity in girls. Physically and psychologically, men and women have fundamental differences. The difference has been created in such a way by Allah. The existence of these differences is not meant to belittle each other, but simply because of the different functions that they will later play. Given these differences, Islam has provided guidance so that each existing fitrah is maintained. Islam wants men to have masculine personalities, and women to have feminine personalities. Islam does not want women to resemble men, and vice versa. For this reason, children must be accustomed from a young age to dress according to their gender. Ibn Abbas ra. Said: Rasulullah SAW. cursed men who pretended to be women and women who pretended to imitate men (HR al-Bukhari)

Fourth, reduce association between the sexes or gender. According to Kurniawati (2003), gender segregation or the tendency of children to play with friends of different genders as different groups, has also emerged in early childhood. At the age of 4 or 5 years, they have begun to refuse to play with children of a different gender. Problems will occur when no control between gender relations over a long period of time. Some children are exposed to different gender lifestyles so that they feel more fit to continue living in that gender (Anas, 2021).

In Islam, this discussion is referred to as ikhtilat. al-Qaradawi (2003) mentions that ikhtilat means mixing in the relationship between men and women without limits. This mixing takes place in conversation, association and communication. Although Islam does not forbid this mixing, but excessive mixing can lead to negative effects

\section{Conclusion}

In conclusion, transgender culture is strictly forbidden in Islam as well as the norms of human life. In addition to changing the creation of god, transgender also brings various side problems including disease and the moral collapse of society. Good sex education needs to be applied so that society understands the concept of gender clearly. There are four main principles of sex education that can be built based on the Islamic framework; , gender education, cultivale shyness, instilling the spirit of masculinity and reduce association between the sexes or gender.

\section{Acknowledgments}

This article is a part of research under Fundamental Research Grant Scheme (FRGS), FRGS/1/2019/SSI03/UNISZA/02/5 and is supported by the Ministry of Education and 
DEVELOPMENT

Vol. 11, No. 1, 2022, E-ISSN: 2226-6348 @ 2022 HRMARS

Universiti Sultan Zainal Abidin (UniSZA)

\section{References}

Anas, W. N. I. W. N., Khairuldin, W. M. K. F. W. K., Mohd, H., \& Ali, A. K. (2020). Rehabilitation of Transsexual Based on Preaching Psychology in Islam. International Journal of Disaster Recovery and Business Continuity. Vol. 11 (1), pp. 682-687Teh, Y.K. (2008). "Hiv-Related Needs for Safety Among Male to Female Transsexuals (Mak Nyah) in Malaysia", Journal of Social Aspects of HIV/AIDS. 5(4), 178-185.

Benjamin, H. (1999). The Transsexual Phenomenon. Electronic Book. Symposium Publishing. http://www.symposion.com/ijt/benjamin/index.html. Accessed on 29 April 2018.

Berne, L. A., Patton, W., and Milton, J. (2000). Australian parents' perception of sexuality education and communication. Journal of Sex Education and Therapy 25, nos. 2/3: 161-8.

Brinkley, E. H. (1999). Caught off guard: Teachers rethinking censorship and controversy. Boston: Allyn and Bacon.

Calimach, A. (2000). World History of Male Love, "Homosexuals Traditions", The Two Spirit Tradition.

Clyne, D. I. (2001). Educating Muslim children in Australia. In Muslimcommunities in Australia, ed. A. Saeed and S. Akbarsaadeh. Sydney:University of NSW Press.

Ghazali, S., Mapjabil, J., Nor, A. M., Samat, N., \& Jaafar, J. L. (2010), "Difusi Ruangan dan Imaginasi Geografi Pelajar Lelaki Transeksual di Universiti Tempatan di Malaysia". Paperwork presented in Persidangan Kebangsaan ke-3 Pembangunan, Sosial dan Persekitaran.Fakulti Sains Sosial dan Kemanusiaan, Universiti Kebangsaan Malaysia. 20-21 July 2010.

Khairuldin, W. M. K. F. B. W., Embong, A. H., Hassan, S. A., Yasin, M. F. M., \& Anas, W. N. I. W. N. (2019). Strategic management in fatwa-making process. Academy of Strategic Management Journal, 18(4), 1-6.

Khairuldin, W. M. K. F. W., Embong, A. H., Anas, W. N. I. W., Mohd, H., \& Ismail, D. (2018). The Application of Technology in the Dissemination of Fatwas: A Study on Religious Institutions in Malaysia, International Journal of Civil Engineering and Technology, 9(7), 2018, pp. 1590-1596.

Mclnerney, D. M., Davidson, N., and Suliman, R. (2000). Personal development, health and physical education in context: Muslim and Catholic perspectives. Australian Journal of Education 44, no. 1: 26-42.

Mohamad, L. Z. (2002), "Lelaki Transeksual dan Pelacuran Nyah di Malaysia: Sejauh Manakah Pertaliannya". Paperwork of Seminar Transeksualiti di Institut Pengajian Tinggi Century Mahkota Hotel Melaka, 23-25 July 2002.

Mulia, S. M. (2009). Understanding LGBT Issues in Islam Promoting The Appreciation of Human Dignity. 2"d CSBR Sexuality Institute - 11-18 September 2009. Istanbul. Accessed from www.asiapasificforum.net/issues/sexual orientation.

Sanjakdar, F. (2009). 'Teacher talk': the problems, perspectives and possibilities of developing a comprehensive sexual health education curriculum for Australian Muslim students. Sex Education, Vol 9 (3), 261-275.

Teh, Y. K. (2001). "Mak Nyahs (Male Transsexuals) in Malaysia: The Influence of Cultural and Religion on their Identity," The International Journal of Transgenderism 5.3 (2001).

Halstead, J. M., \& Reiss, M. J. (2003). Values in sex education: From principles to practice. London: RoutledgeFalmer. 